\title{
Konstruksi Identitas Tionghoa melalui Difusi Budaya Gambang Kromong: Studi Kasus Film Dikumenter Anak Naga Beranak Naga
}

\author{
Umilia Rokhani ${ }^{1}$, Aprianus Salam, dan Ida Rochani-Adi \\ Prodi Studi Ilmu-ilmu Humaniora, Fakultas Ilmu Budaya, Universitas Gadjah Mada Yogyakarta
}

\begin{abstract}
ABSTRAK
Gambang kromong menjadi kesenian campur yang mampu bertahan di tengah pembatasan terhadap ruang gerak masyarakat Tionghoa. Keberadaan kesenian ini sekaligus menjadi atribut budaya yang mampu menjadi unsur pembangun identitas masyarakat Tionghoa. Identitas Tionghoa melalui kesenian gambang kromong memunculkan konstruksi yang berbeda terkait dengan kebertahanan kesenian tersebut. Wacana ini muncul pada film dokumenter Anak Naga Beranak Naga. Konstruksi identitas ini dikaji dengan mempergunakan teori Bhabha tentang konsep ruangantara. Penelitian ini menggunakan pendekatan konstruktivisme sosial untuk melihat makna-makna subjektif dari pengalaman-pengalaman subjek pelaku kehidupan masyarakat Tionghoa di Indonesia. Melalui pendekatan ini dapat diketahui bahwa konstruksi identitas masyarakat Tionghoa melalui kesenian gambang kromong bersifat heterogen. Konsep kehidupan berkesenian yang cair dan mampu menembus batas perbedaan terepresentasi pada bentuk instrumen, lagu-lagu yang dibawakan maupun fungsional dari pertunjukan itu sendiri. Hal ini menunjukkan bahwa identitas masyarakat Tionghoa juga dikonstruksi secara cair oleh masyarakat, bukan hanya dalam menghadapi perbedaan dan permasalahan etnisitas tetapi juga kemampuan beradaptasi terhadap perkembangan zaman. Dengan konstruksi yang cair tersebut, konstruksi identitas masyarakat Tionghoa menjadi bersifat pragmatis dan dis-identifikasi.
\end{abstract}

Kata kunci: Gambang Kromong, Tionghoa, difusi budaya, Anak Naga Beranak Naga

\begin{abstract}
Construction of Tionghoa Identity through Cultural Diffusion of Gambang Kromong: Case Study of Documentary Film Anak Naga Beranak Naga. Becoming a mixed culture, Gambang Kromong was able to survive during the time when the moving space of Tionghoa society was being restricted. The existence of this musical art became a cultural attribute, which was capable of being a building element for the identity of Tionghoa society. Meanwhile, as well as its existence, the identity of Tionghoa society has always become a conflicting element. It, through the musical art of Gambang Kromong, presented a different construction as related to the survival of this musical art. This discourse appears in the documentary film of Anak Naga Beranak Naga. This identity construction is, then, analyzed using the theory of Bhabha about the concept of in-between. The method applied is social constructivism approach in order to find out subjective meanings revealed from experiences of the live subjects of Tionghoa society in Indonesia. By using this method, it could be found out that the identity construction of Tionghoa society, through gambang kromong musical art, is heterogonous. The concept of fluidly art life, which was also able to push the boundaries, is well represented in its instrument forms; played songs; as well as the functionality of gambang kromong performance. It shows that the identity of Tionghoa society was constructed by the society themselves, not only in struggling against difference and ethnicity problems but also in its ability to adapt to changing times. Its fluid construction has made the identity construction of Tionghoa society becomes pragmatic as well as dis-identified..
\end{abstract}

Keywords: Gambang Kromong, Tionghoa, cultural diffusion, Anak Naga Beranak Naga

1 Alamat korespondensi: Prodi S3 Ilmu Humaniora, FIB UGM. Jln. NUsantara No.1 Bulaksumur, Catur Tunggal, Yogyakarta 55281. E-mail: umilia_erha@yahoo.co.id; HP: 082221953779 


\section{Pendahuluan}

Identitas Tionghoa merupakan identitas yang senantiasa diambangkan di Indonesia. Keberadaan masyarakat Tionghoa yang ditempatkan sebagai Liyan bagi sebagian besar rakyat Indonesia dan telah turun temurun berpegang pada konsep tersebut semakin mempersulit ruang gerak kehidupan masyarakat Tionghoa di Indonesia. Hal ini ditambah dengan kebijakan diskriminatif Tionghoa yang diterapkan oleh pemerintah sejak zaman kolonial hingga berakhirnya Orde Baru. Tumbangnya kepemimpinan pemerintahan Orde Baru membawa perubahan besar terhadap pengakuan dan ruang gerak kehidupan masyarakat Tionghoa di Indonesia. Namun demikian, identitas Tionghoa di Indonesia tidak serta merta terbentuk dengan jelas dengan adanya perubahan arah kebijakan tersebut.

Identitas Tionghoa masih senantiasa dikonstruksi melalui berbagai sudut pandang baik dari internal masyarakat Tionghoa itu sendiri maupun eksternal yaitu masyarakat di luar masyarakat Tionghoa itu sendiri. Konstruksi identitas ini dipengaruhi salah satunya melalui kesenian yang berkembang di tengah masyarakat Tionghoa itu sendiri yang pada akhirnya juga dinikmati oleh masyarakat luas. Posisi kesenian yang lebih lentur terhadap berbagai arah kebijakan menempatkan kesenian ini seringkali mampu bertahan dalam kondisi yang disudutkan dan berupaya dimatikan eksistensinya sekalipun.

Kesenian gambang kromong merupakan salah satu kesenian yang mampu bertahan di tengah masyarakat Tionghoa di Indonesia pada khususnya dan masyarakat Indonesia pada umumnya. Kebertahanan kesenian ini bukan suatu hal yang mudah dilakukan. Seperti yang disampaikan Van Puersen (2005) tentang strategi kebudayaan bahwa perkembangan kebudayaan dapat dipakai dalam situasi-situasi yang selalu berubah yang dialami oleh manusia melalui tiga tahap yaitu mitis, ontologis dan fungsional. Dalam hal ini, kesenian sangat dekat dengan fungsional asal mampu memberi arti pada situasi-situasi yang konkret. Demikian pula halnya dengan eksistensi kesenian gambang kromong yang mampu menjadi unsur pemeta identitas ke-"tionghoa"-an dengan menafsir pada situasi-situasi yang konkret sekaligus melihat pada fungsional kesenian tersebut.

Dalam ranah ke-"tionghoa"-an, kesenian ini turut menjadi salah satu atribut budaya yang mampu menjadi unsur pembangun identitas bagi masyarakat Tionghoa. Kebertahanannya teruji di tengah tekanan untuk mematikan eksistensi budaya Tionghoa berdasar Inpres No. 14/1967 tentang Agama, Kepercayaan dan Adat Istiadat Tionghoa. Undang-undang ini melarang perayaan hari raya Tionghoa, penggunaan bahasa Mandarin dan adat istiadat Tionghoa di muka umum. Dengan adanya wacana diskriminasi tersebut, besarnya peranan kesenian ini dalam kehidupan masyarakat Tionghoa muncul, meskipun fungsinya sebagai salah satu pembentuk unsur identitas masih perlu dikaji lebih dalam, mengingat keberadaan jenis kesenian ini tidak sepenuhnya murni sebagai kesenian Tionghoa asli yang dibawa dan dikembangkan dari tanah leluhur.

Menonjolnya kesenian ini dalam kehidupan masyarakat Tionghoa menjadi satu potret yang diangkat dalam beberapa film indie, baik narasi maupun dokumenter. Salah satu kesenian yang banyak diangkat adalah kesenian gambang kromong. Kesenian ini menjadi kesenian akulturasi sebagai bentuk difusi budaya atas keberadaan masyarakat Tionghoa yang merupakan masyarakat diasporik di lingkup wilayah Indonesia. Meskipun keberadaan masyarakat Tionghoa telah turun temurun dan sebagian besar tidak lagi menganggap dirinya sebagai masyarakat diasporik melainkan sudah menyatu menjadi bagian dari Indonesia.

Gambang kromong adalah kesenian yang berkembang di kalangan masyarakat ibu kota dan wilayah Jawa Barat. Keberadaan kesenian ini telah ada sejak lama bahkan sebelum zaman kolonial. Keberadaannya tentu saja mengalami pasang surut menyesuaikan perubahan zaman dan kebijakan yang diberlakukan terhadap masyarakat Tionghoa. Hal ini pula yang dapat dijadikan salah satu unsur indikator bahwa kesenian gambang kromong juga mengkonstruksi identitas masyarakat Tionghoa seiring pasang surut perkembangannya yang mengikuti sejarah keberadaan masyarakat Tionghoa di Indonesia karena keberadaannya 
yang membentuk kelompok-kelompok komunitas. Komunitas sebagai satuan sosial yang holistik membentuk unsur-unsur kebudayaan baik intern maupun ekstern. Komunitas membentuk cirinya sebagai satuan sosial melalui ciri-ciri kebudayaan yang dilekatkan kepadanya seperti ritual-ritual, upacara-upacara, lambang-lambang dan lain sebagainya. Ciri-ciri atau penanda suatu komunitas melalui ritual, upacara, lambanglambang memunculkan kebudayaan folk yang tidak mengacu pada kebudayaan primitif dan juga belum sampai pada kebudayaan modern. Umumnya, kebudayaan ini dapat ditemui di pedesaan atau di perkotaan tetapi bukan pada golongan masyarakat elit. Kebudayaan folk ditemukan pada komunitas kecil. Komunitas kecil tidak terdeskripsikan lokasi di desa atau kota. Namun pada umumnya, komunitas kecil lebih merujuk pada pedesaan. Untuk memperjelasnya, Redcliffe (Koentjaraningrat, 1990) membuat pembedaan kriteria untuk penentuan komunitas kecil, yaitu: distinctiveness (pembeda yang jelas dengan komunitas lain melalui identitas yang khas), smallness (wilayah dengan penduduk yang relatif kecil sehingga saling mengenal, berinteraksi dan terlihat nilai kepribadiannya), homogeneity (memiliki sifat keseragaman atau homogen), and all-providing self-sufficiency (kebutuhan hidup yang terbatas sehingga mampu dipenuhi sendiri tanpa harus bergantung dengan pihak luar).

Salah satu wacana yang muncul terkait dengan keberadaan kesenian gambang kromong sebagai bagian dari konstruksi identitas masyarakat Tionghoa adalah melalui film Anak Naga Beranak Naga. Film ini mengupas mengenai kesenian tersebut dan kelompok-kelompok kesenian yang melestarikannya. Keberadaan kelompok tersebut tidak lepas dari kehidupan masyarakat Tionghoa sebagai pelaku dan penikmat. Keberadaannya juga tidak lepas sebagai kesenian yang sering muncul dalam perayaan yang diadakan oleh masyarakat Tionghoa. Oleh karena itu, objek film ini layak dikaji untuk melihat korelasi keberadaan kesenian gambang kromong terhadap konstruksi identitas masyarakat Tionghoa itu sendiri. Tujuannya untuk memberikan kebaruan wacana mengenai konstruksi identitas ke-"tionghoa"-an melalui strategi difusi budaya kesenian gambang kromong melalui korelasi bentuk kesenian dengan konstruksi identitas itu sendiri. Menurut Budiman (2013) tataran dimensi makna pada film dapat diungkapkan melalui tanda-tanda konotatif yang membangun signifikasi pada tataran simbolik. Seperti pada film Opera Jawa karya sutradara Garin Nugroho, karya instalasi pada film tersebut sangat koheren dalam membangun proses signifikasi mise-en-scène beberapa adegan yang membentuk retorika dengan pemaknaan tertentu.

Konsep identitas itu tidak terpolarisasi pada dikotomi Barat dan Timur. Dalam konsep yang dikemukakan Bhabha (1994, hal. 1-2), bahwa identitas terbangun melalui konsep in-between Dengan demikian, tidak terdapat identitas yang dapat dikatakan murni atau tunggal. Hal ini menyangkal konsep Said (2010) yang menyatakan bahwa konsep identitas hanya terpolarisasi pada dikotomi Barat dan Timur. Lebih lanjut, konsep Bhabha ini menekankan adanya tempat untuk memperluas strategi diri, baik sebagai individu maupun komunal, yang menghasilkan tanda-tanda adanya identitas baru, jenis-jenis kolaborasi yang inovatif tentang konsep diri sekaligus persaingan dalam upaya untuk mendefinisikan identitas masyarakat itu sendiri. Dengan demikian, pemahaman atas konsep tersebut membawa pada pemahaman adanya penegosiasian budaya antara budaya satu dengan lainnya yang menghasilkan suatu budaya baru. Penegosiasian budaya tersebut yang membuka terjadinya peniruan (mimikri) sebagai bentuk dekonstruksi dikotomi BaratTimur sebagai konsekuensi adanya ruang-antara dan sikap yang tidak menentu (ambivalensi) dari bentuk identitas di dalamnya.

Pendekatan yang dipergunakan untuk menganalisis konstruksi identitas berdasarkan pada korelasinya dengan kesenian gambang kromong adalah pendekatan konstruktivisme sosial. Konstruktivisme sosial menegaskan bahwa manusia senantiasa terlibat dengan dunia mereka dan berusaha memahami berdasarkan perspektif historis dan sosialnya sendiri (Creswell, 2012: 12). Oleh karena itu, metode yang dipergunakan dalam penelitian ini adalah analisis wacana. Dalam hal ini, dikaji makna-makna subjektif atas pengalaman- 
pengalaman kehidupan masyarakat Tionghoa di Indonesia melalui kehidupan gambang kromong, baik pelaku kesenian maupun sistem kesenian itu sendiri. Kajian tersebut melihat relasi wacana dengan konstruksi identitas yang terbangun melalui kehidupan pelaku maupun kehidupan berkeseniannya terkait dengan tradisi yang dilakukan oleh masyarakat Tionghoa. Oleh karena itu, kajian historikal dan kultural penting untuk diungkapkan sehingga diperoleh gambaran latar belakang yang kompleks kehidupan masyarakat Tionghoa dan perkembangan kesenian gambang kromong di Indonesia. Gambaran yang kompleks tersebut akan membantu dalam melihat konstruksi identitas masyarakat Tionghoa sebagai masyarakat diasporik.

\section{Korelasi Sejarah Masyarakat Tionghoa dengan Perkembangan Kesenian Gambang Kromong}

Pemetaan ke-"tionghoa"-an harus dilihat dari berbagai aspek kehidupan yang dapat dirunut dari sejarah kehidupan masyarakat Tionghoa di Indonesia mengenai ruang gerak dan eksistensi mereka maupun media sebagai wadah untuk melihat bentuk identitas ke-"tionghoa"-an itu sendiri. Kehidupan masyarakat Tionghoa telah muncul pada zaman kerajaan Majapahit yang dipimpin oleh Prabu Brawijaya sekitar abad ke-7.

Pada masa penjajahan Belanda, secara perlahan masyarakat Tionghoa didatangkan dan memasuki kantong-kantong pemukiman untuk melakukan pekerjaan sebagai buruh di Batavia. Pemerintah Belanda sengaja tidak memilih masyarakat lokal karena dikhawatirkan akan terjadi pemberontakan dari masyarakat lokal terhadap Belanda. Menurut sinolog Eddie Prabowo, alasan pemilihan masyarakat Tionghoa sebagai buruh pilihan penjajah Belanda, yaitu: pertama, masyarakat Tionghoa dianggap lebih memiliki etos kerja yang tinggi; kedua, upah kerja masyarakat Tionghoa dinilai murah (rendah); dan ketiga, karena masyarakat Tionghoa merupakan pendatang dan bukanlah masyarakat lokal yang notabene dijajah Belanda. Sementara menurut David Kwa, seorang budayawan Tionghoa-Indonesia, bahwa setelah Batavia didirikan yaitu setelah Jayakarta dihancurkan, masyarakat Tionghoa didatangkan dari Banten dengan berbagai cara, antara lain: dibujuk, dipaksa, diculik dan dibelokkan ke kota yang tidak memiliki Sumber Daya Manusia tenaga kerja untuk membangun Batavia. Masyarakat Tionghoa tidak hanya memiliki keahlian berdagang, mereka memiliki berbagai keahlian seperti bertukang dan memasok makanan bagi Belanda.

Tahap berikutnya berlanjut ketika Belanda telah membangun sarana dan prasarana fisik, masyarakat Tionghoa didatangkan langsung dari Tiongkok. Pada mulanya, masyarakat Tionghoa pada waktu itu hidup secara bebas tersebar di perkotaan. Mereka tidak hidup di dalam beteng karena Belanda dalam waktu tertentu berusaha mengembangkan pertanian di luar beteng. Namun kondisi itu hanya berlangsung sampai tahun 1740 karena pada tahun tersebut terjadi pembantaian besar-besaran di Batavia terhadap masyarakat Tionghoa. Masyarakat Tionghoa pada waktu itu dianggap akan melakukan pemberontakan besarbesaran. Hal ini disebabkan oleh konflik internal di jajaran elit politik tetapi yang menjadi korban adalah masyarakat Tionghoa. Pola ini menjadi pola berulang yang terjadi masyarakat Tionghoa, termasuk peristiwa Mei 1998. Die Jung Fu menyatakan kisaran korban mencapai 10.000 orang mati terbunuh dalam peristiwa 1740 tetapi mungkin lebih dari kisaran tersebut karena ada akronim tentang Kali Angke sedangkan masyarakat Tionghoa pada masa itu mencapai 200-300 ribu. Kata 'angke' dalam bahasa Hokkian berarti kali merah. Hal ini menandai bahwa aliran Kali Angke berubah menjadi merah karena darah masyarakat Tionghoa yang menjadi korban dan mewarnai aliran Kali Angke pada tanggal 11 Oktober 1470.

Kejadian itu menyebabkan masyarakat Tionghoa di Batavia dilarang untuk tinggal di dalam beteng dan harus berpindah ke luar beteng yang telah ditentukan tempatnya yaitu suatu tempat bernama Glodok. Namun pada dasarnya, Glodok masih berada dalam jangkauan pantauan Belanda yaitu dalam kisaran satu tembakan peluru. Artinya, tempat yang terletak di antara benteng dan pemukiman baru Tionghoa itu harus dikosongkan dengan tujuan agar mudah diawasi. 
Dengan demikian, apabila terjadi lagi kerusuhan, Belanda akan dengan cepat membombardir dan menghancurkan tempat tersebut.

Glodok selanjutnya berkembang menjadi area pecinan sampai saat ini. Konsep pecinan muncul dari aturan pemerintah kolonial tentang wijkenstelsel. Aturan wijkenstelsel yaitu aturan pemukiman menurut pembagian kelompok etnis. Aturan tersebut yang mengatur orangorang Tionghoa diharuskan untuk tinggal di kantong-kantong pemukiman Tionghoa yang disebut dengan pecinan (Kustedja, 2012, hal. 110). Pecinan itu sendiri hingga saat ini masih dapat ditemukan tersebar di berbagai wilayah Indonesia. Melalui peraturan tersebut, ruang gerak masyarakat Tionghoa akan terpantau oleh pemerintah kolonial. Hal ini dilakukan untuk melemahkan posisi masyarakat Tionghoa dalam masyarakat secara luas.

Resinifikasi atau pencinaan kembali di tengah keberadaannya sebagai masyarakat diasporik bukanlah hal yang mudah. Kerinduan akan ingatan tanah leluhur menjadi salah satu alasan dipertahankannya kebudayaan leluhur meskipun membutuhkan ruang beradaptasi dengan kebudayaan setempat atau kebudayaan lainnya yang juga datang dan berbaur di wilayah yang sama. Seperti halnya kesenian gambang kromong yang identik menjadi salah satu ciri kesenian Tionghoa hasil difusi budaya di daerah Jakarta. Kesenian ini merupakan kesenian campur (eklektik) dari berbagai unsur budaya yang ada di wilayah Batavia. Sekitar tahun 1650-1700 akhir ketika berbagai orang dari seluruh wilayah Indonesia didatangkan oleh Belanda. Gambang kromong itu muncul awalnya di Jakarta. Jadi bukan musik Cina Beteng seperti sangkaan orang pada umumnya. Pesebaran musik ini dari Jakarta menyebar ke barat yaitu daerah sekitar Tangerang; ke selatan yaitu daerah komunitas-komunitas Tionghoa peranakan di sekitar daerah Bogor atau daerah Cileungsi, Jonggol, sampai ke Ciampea dan Gunung Sindur; ke daerah timur yaitu komunitas Tionghoa di daerah Bekasi, Babelan, Teluk Buyur dan Teluk Angsa.

Dapat dipastikan bahwa masyarakat kelas menengah ke atas cenderung massive dan cenderung tidak membuka diri dengan budaya-budaya setempat terlalu banyak, sedangkan masyarakat menengah ke bawah karena ketiadaan bargaining position yang cukup kuat maka memaksa mereka membuka diri agar bisa diterima dengan masyarakat setempat, salah satunya dengan memadukan dua budaya ini. Oleh karena itu, budaya cokek dan gambang kromong dapat dipastikan berkembang bukan di pusat-pusat kota melainkan di pinggiranpinggiran.

Namun sekarang perkembangan kesenian tersebut semakin meluas, bukan hanya Jakarta saja tetapi menjadi Jabotabek (Jakarta, Bogor, Tangerang, Bekasi), Banten, bahkan hingga ke Cirebon. Melalui kesenian ini, konstruksi masyarakat Tionghoa yang tumbuh dari berbagai latar budaya dan tingkat sosio-ekonomi yang beragam dipaparkan sebagai bagian dari perkembangan budaya gambang kromong. Dikatakan beragam karena para pelaku kesenian gambang kromong sebagian besar merupakan masyarakat menengah ke bawah. Hal ini tentu saja membongkar gambaran masyarakat Tionghoa yang distereotipkan sebagai masyarakat berkelas dan dengan tataran kehidupan sosio-ekonomi menengah ke atas.

\section{Bentuk Kesenian Gambang Kromong dalam Film Anak Naga Beranak Naga}

Budaya menjadi atribut utama yang menjadi penanda identitas suatu masyarakat. Ranah budaya pula yang menjadi batas termudah untuk ditembus dengan mudah melalui interaksi antarkelompok masyarakat yang berbeda. Oleh karena itu, budaya pula yang dapat dijadikan sebagai media paling kuat untuk menanamkan nilai-nilai, salah satunya mengenai pembentukan identitas. Bercampurnya suatu budaya yang bertahan hidup di suatu kalangan masyarakat dengan budaya baru yang datang merupakan suatu bentuk difusi budaya. Difusi budaya ini yang menjadi salah satu cara bertahannya masyarakat diasporik di lingkup tanah tempat tinggal mereka. Difusi budaya tersebut dapat berbentuk akulturasi maupun asimilasi.

Konstruksi masyarakat Tionghoa tumbuh dari berbagai latar budaya dan tingkat sosio- 
ekonomi yang beragam. Hal ini terkait dengan kehidupan orang pinggiran, bukan orang yang hidup di tengah perkotaan. Kesenian gambang kromong menampilkan budaya pinggiran yang pelaku seninya merupakan orang dari kalangan Tionghoa menengah ke bawah. Menurut Afif (2012: 89), orang-orang Tionghoa yang basis kehidupan ekonominya lemah dan kesulitan melakukan mobilitas vertikal lebih memilih untuk hidup di kawasan pinggiran dan membaur dengan penduduk pribumi merupakan pilihan yang paling menguntungkan. Kondisi tersebut memunculkan golongan masyarakat Tionghoa yang lebih terbuka menerima pengaruh kebudayaan penduduk pribumi dan tidak terlalu fanatik dengan kebudayaan leluhur mereka. Oleh karena itu, kesenian ini tumbuh dari komunitas pekerja atau buruh yang membawa kesenian Tiongkok yang tidak lagi kental dalam ingatan sehingga keberadaannya membaur dengan kesenian setempat.

Konstruksi identitas yang dilekatkan pada masyarakat Tionghoa juga membangun stereotipstereotip sebagai bentuk penyederhanaan identitas. Stereotip yang digambarkan melalui film Anak Naga Beranak Naga disampaikan oleh Ukat Sukadi sebagai pelaku seni yang menjalankan usaha jasa hiburan melalui kesenian gambang kromong. Kesenian tersebut bagi Ukat bertujuan untuk melestarikan warisan orang tua, juga untuk memenuhi kebutuhan seperti rumah, kendaraan maupun menunaikan ibadah haji. Ungkapan Ukat Sukardi ini menunjukkan bahwa agama yang dianut pun tidak lagi mengikuti tradisi masyarakat Tiongkok, Confusianisme. Demikian pula halnya dengan dua narasumber lain yang juga pelaku seni gambang kromong dalam film Anak Naga Mencari Naga menyatakan bahwa kesenian gambang kromong dipertahankan karena sudah menyatu dalam kehidupan mereka. Namun berbeda dengan Ukat, kesenian gambang kromong tidak dapat dipergunakan untuk menjadi mata pencaharian karena tidak setiap saat ada permintaan untuk pentas pertunjukan. Oleh karena itu, mereka tidak dapat menggantungkan pemasukan keuangan untuk hidup melalui kesenian gambang kromong. Dari wacana tersebut terlihat bahwa tidak semua kehidupan masyarakat Tionghoa masuk dalam tataran masyarakat kaya. Stereotip yang menghomogenkan masyarakat Tionghoa sebagai masyarakat yang memiliki keterjaminan ekonomi terbantahkan dengan gambaran yang dimunculkan pada film Anak Naga Beranak Naga. Dengan demikian, masyarakat dalam ruang antara seperti dikatakan Bhabha tidak dapat dihomogenkan dengan pemaksaan klasifikasi stereotip. Seperti halnya masyarakat dalam dikotomi Timur dan Barat, juga hidup sebagai manusia yang heterogen karena tidak adanya kemurnian budaya.

Kesenian gambang kromong ini muncul dimulai saat pada waktu luang para peranakan ini ingin memainkan kesenian yang biasa dimainkan oleh leluhur mereka dari wilayah di sekitar Zhangzhou, Xiamen, dan Quanzhou di Propinsi Fujian (Hokkien) Selatan. Kesenian ini memadukan jenis-jenis instrumen dari dua wilayah budaya yaitu instrumen musik tradisi masyarakat Sunda atau Jawa yaitu gambang dan instrumeninstrumen dari wilayah budaya leluhur masyarakat Tionghoa yaitu instrumen gesek berupa sukong (su-kong), tehyan (the-hian), dan kongahyan (konga-hian); instrumen petik berupa jihyan (ji-hian), samhyan (sam-hian), dan gitar guekim (gueq-kim); flute masyarakat RRT (bangsing) dan ningning yang dikombinasi dengan instrumen gambang (xylophone). Gambang ini dipergunakan untuk menggantikan instrumen kecapi dari RRT yaitu yang-khim (yangqin) yang dimainkan dengan cara dipukul dengan bahan yang terbuat dari bambu yang datar. Pada perkembangan berikutnya di tahun 1880an, atas inisiatif Kapitan Teng Tjoe dari Pasar Senen ditambahkan instrumen kromong, kendang, kempul dan gong untuk pertunjukan orkestra gambang kromong.

Inisiatif tersebut menunjukkan bahwa kesenian gambang kromong merupakan kesenian perpaduan yang instrumennya terbentuk dari konsepsi substitusi dari instrumen asli Tiongkok dengan instrumen etnis di Indonesia dan dilengkapi dengan instrumen-instrumen etnis lainnya. Dalam hal ini, instrumen menjadi penanda adanya integrasi dua kebudayaan yang bersatu membentuk kesenian yang baru. Hal ini menunjukkan bahwa instrumen tidak hanya muncul sebagai penanda integrasi dua atau lebih suatu kesenian tetapi 
dengan terbentuknya suatu kesenian baru akibat adanya perpaduan kesenian tersebut menjadikan instrumen sebagai penanda dari identitas baru suatu kelompok masyarakat. Hal tersebut ditunjukkan salah satunya dengan penanda instrumen erhu tidak lagi menjadi instrumen yang dimunculkan secara menonjol, melainkan penggunaan instrumen tehyan dalam pertunjukan gambang kromong. Dengan demikian, melalui penanda tersebut dapat diketahui bahwa kesenian gambang kromong menjadi entitas baru yang muncul dari perpaduan beberapa kesenian.

Pada dasarnya, sejak awal kemunculan kesenian ini, percampuran budaya telah terepresentasi dalam penggunaan instrumen-instrumen yang digunakan dalam kesenian gambang kromong. Percampuran budaya tersebut terjadi karena masuk dan bercampurnya berbagai jenis masyarakat yang membawa budayanya masing-masing ke satu wilayah budaya, atau budaya tersebut yang bergerak keluar dan berekspansi atas pengaruh budayanya. Dengan demikian, sering muncul bentuk budaya baru hasil percampuran dari beberapa budaya aslinya. Budaya baru tersebut membentuk konsep baru dan penanda-penanda yang baru yang walaupun unsur dari budaya-budaya aslinya masih terlihat tetapi kemungkinan pemaknaannya berbeda. Namun, di luar dari itu terdapat pula pengaruh eksternal berupa perkembangan teknologi yang sekalipun menghadirkan nuansa yang hampir sama dengan aslinya, tetapi terdapat perbedaan nilai di dalamnya. Perkembangan teknologi ini terkait dengan pengaruh masuknya instrumeninstrumen musik Barat yang memiliki karakter dan pola permainan yang berbeda dengan musik tradisi sehingga dalam perkembangan selanjutnya permainan gambang kromong dalam berbagai event melibatkan generasi muda untuk mengiringi lagulagu khas gambang kromong tetapi mempergunakan instrumen-intrumen musik Barat seperti gitar bass, keyboard, gitar elektrik dan lain sebagainya untuk menggantikan atau melengkapi permainan alat-alat musik tradisional gambang kromong. Dengan percampuran instrumen-instrumen Barat, klasifikasi instrumen musik tradisi yang diakui oleh dunia yaitu membranophone, aerophone, idiophone dan chardophone telah mengalami pengembangan yang cukup signifikan dengan adanya technophone. Atribut yang membentuk satu pertunjukan penuh dalam kesenian gambang kromong seperti lirik lagu maupun tempo irama dari lagu yang dimainkan dapat dijadikan penanda adanya difusi budaya yang membentuk suatu identitas baru yang berbeda dengan identitas budaya leluhur masyarakat Tionghoa.

Kesenian gambang kromong dipentaskan dalam ragam adat masyarakat Tionghoa. Hal ini yang mendekatkan kesenian ini secara lebih identik pada kehidupan masyarakat Tionghoa. Dalam film Anak Naga Beranak Naga, kesenian ini dipentaskan untuk memperingati ulang tahun berdirinya tempat ibadah seperti kelenteng, acara pernikahan, upacara pemakaman atau dalam perayaan hari besar masyarakat Tionghoa. Keterkaitan erat pertunjukan kesenian gambang kromong dengan tradisi masyarakat Tionghoa menunjukkan bahwa kehidupan kesenian gambang kromong mengikatkan diri pada tradisi TionghoaIndonesia.

Bentuk kebertahanan budaya Tionghoa lainnya adalah berkolaborasi dalam kesenian. Kesenian tradisi beberapa wilayah di Indonesia dipengaruhi oleh kesenian dari Tiongkok. Salah satu kesenian yang berakulturasi adalah kesenian gambang kromong. Kesenian ini mempergunakan slendro Tiongkok yaitu lima nada (gong, shang, jiao, zheng dan yu). Sementara, gamelan di Jawa mempergunakan tangga nada slendro (lima tangga nada/ji-ro-lu-mo-nem) dan pelog (tujuh tangga nada/ji-ro-lu-pat-mo-nem-pi). Kebertahanan budaya melalui akulturasi ini berlangsung secara natural, alami dan perlahan sehingga ciri dan kekhasan sebagai budaya Tionghoa menjadi bersifat cair pula. Peleburan ini tidak semestinya dinilai sebagai lunturnya budaya Tionghoa sehingga menempatkan masyarakat Tionghoa sebagai etnis keturunan yang sudah tidak memiliki kemurnian darah karena percampuran budaya yang dihadapinya. Sebaliknya, budaya yang cair dan fleksibel ini menunjukkan bentuk kesadaran masyarakat Tionghoa sebagai bagian dari masyarakat diaspora.

Harapan dan kerinduan akan tanah leluhur tidak akan semudah itu dilepaskan sehingga tidak 
akan budaya leluhur yang dibawa oleh masyarakat Tionghoa kemudian dapat ditanggalkan begitu saja tanpa adanya proses percampuran budaya. Dalam hal ini, kehidupan subjek dalam rentang kenangan dan harapan muncul menjadi penanda-penanda terjadinya adaptasi budaya. Penanda budaya leluhur yang dibawa atau muncul hanya sebagai kenangan akan berupaya dipertahankan.

Pada dasarnya, peta pesebaran budaya dapat dilihat dari penanda-penanda yang masih ada atau masih ditinggalkan di wilayah setempat. Proses akulturasi masih dapat dilihat dari penanda budaya tersebut. Seperti pesebaran kebudayaan perunggu yang berasal dari Mesopotamia pada 3000 SM menyebar ke Tiongkok dan Vietnam pada 2000 SM dan kemudian masuk ke wilayah Indonesia. Hal ini meninggalkan penanda-penanda budaya dengan adanya peninggalan alat-alat perunggu seperti nekara (genderang perunggu) di beberapa wilayah Indonesia seperti Sumatera, Jawa, Nusa Tenggara, Bali, Sangean Rote, Leti, Selayar, Kei, dan Alor (Haryanto, 2015: 122).

Persebaran budaya perunggu tersebut tentu saja diikuti dengan pesebaran budaya lainnya. Aplikasi budaya perunggu dapat dilihat dari bentukbentuk penerapan seperti instrumen gong. Pada masing-masing daerah, penanda budaya tersebut memiliki kemiripan bentuk, cara memainkan, tetapi beda penamaan. Penamaan gong berbedabeda termasuk turunan instrumennya seperti agung (Sumatera, Mindanau, Filipina Selatan), kenong, kempul, dan bonang (Jawa), tong gu seperti gong tanpa pencu dan berukir naga (Tiongkok), mah eng (Kalimantan), bheri (Bali). Selain gong, juga terdapat instrumen penanda akulturasi budaya lainnya seperti rebab. Rebab merupakan instrumen gesek tradisional. Rebab di Kalimantan Tengah belum diketahui merupakan bentuk pengaruh dari Tiongkok, Melayu, atau Jawa. Rebab ini berbentuk seperti alat musik gesek berdawai dua yang disebut erhu (Tiongkok), atau tehyan (Betawi). Ketiganya memiliki kemiripan bentuk sebagai dasar penanda. Namun, ketiganya dibuat dari bahan membran yang berbeda. Membran erhu dibuat dari kulit ular, membran tehyan dibuat dari papan tipis, sedangkan rebab dibuat dari tempurung kelapa dengan membran yang terbuat dari berbagai macam bahan (Haryanto, 2015: 142). Material rebab Dayak mengadopsi dua instrumen yaitu mempergunakan tempurung kelapa seperti tehyan dan mempergunakan kulit ular sebagai membran seperti pada erhu. Sementara itu, membran pada rebab Jawa juga mempergunakan jenis kulit hewan seperti erhu tetapi dari kulit kambing. Semua instrumen tersebut mempergunakan dawai dua seperti erhu. Instrumen yang juga mempergunakan material dari kulit hewan lainnya adalah instrumen dari Jepang. Instrumen tersebut adalah samisen, tetapi samisen mempergunakan dawai tiga dengan cara dimainkan dengan dipetik, bukan digesek seperti erhu, tehyan, rebab Jawa maupun rebab Dayak. Dengan demikian, peta pesebaran Tionghoa menyebar di berbagai wilayah tetapi dengan perkembangan masing-masing yang memunculkan karakteristik yang berbeda satu dengan yang lain baik dilihat dari material instrumen maupun cara memainkannya.

Penanda instrumen sebagai sarana berinteraksi antara masyarakat Tionghoa dengan masyarakat non Tionghoa muncul pada film Anak Naga Beranak Naga. Penanda instrumen pada film tersebut lebih dipilih tehyan untuk ditampilkan sebagai penanda budaya hibrid dan tidak menampilkan permainan instrumen erhu yang menjadi identitas asli tanah Tiongkok. Hal ini menunjukkan bahwa konstruksi kehidupan masyarakat Tionghoa di Indonesia telah membentuk identitas baru meski tidak meninggalkan sepenuhnya pengaruh budaya leluhur mereka.

Sementara itu, lagu yang dinyanyikan dalam kesenian gambang kromong dapat dibedakan menjadi tiga kategori yaitu lagu Pobin, lagu Dalem, dan lagu Sayur (Kwa, 2012: 320-323). Lagu Pobin merupakan lagu yang dimainkan oleh pelaku seni gambang kromong secara intrumentalia. Lagu ini merupakan lagu yang merujuk pada lagu tradisional leluhur masyarakat Tiongkok di selatan Propinsi Fujian (Hokkien) di Tiongkok bagian selatan. Lagu Pobin ini termasuk dalam tataran lagu tertua yang dimainkan sebagai repetoar dalam gambang kromong.

Beberapa lagu Pobin masih dapat dimainkan sekalipun tidak semua pemain mampu memainkannya. Beberapa lagu Pobin 
ini digunakan dalam acara pernikahan tradisi Tionghoa maupun acara pemakaman. Lagu Pobin yang masih mampu dimainkan biasanya karena sering dimainkan. Dengan demikian, lagu Pobin tidak sering dimainkan karena ketidakmampuan membaca notasi musik yang mempergunakan karakter Tiongkok yang biasa digunakan untuk dimainkan pada lagu Hokkien Selatan. Oleh karena itu, hanya pemusik tertentu yang dapat memainkan lagu Pobin. Sekalipun pemusik dapat memainkan lagu Pobin, hal itu dilakukan karena kebiasaan sehingga notasi musik seringkali tidak dibaca atau diabaikan. Pemusik mengandalkan kekuatan memori mereka. Karena kendala itu pula, pemusik yang dapat memainkan lagu Pobin semakin sedikit. Dalam hal ini, keberadaan lagu Pobin bagi masyarakat diaspora menjadi berkonsep sebagai musik budaya yang berkembang melalui tradisi lisan. Seperti yang dijelaskan oleh Titon (1984: 7) bahwa tradisi lisan tidak memiliki instruksi formal sehingga pemusik dapat menemukannya sedikit demi sedikit hanya dengan melihat dan mendengar, biasanya hal tersebut terjadi selama bertahun-tahun. Keberadaan musik tersebut akan tumbuh dalam konsep keluarga pemusik, sehingga perbendaharaan musik itu ditularkan dalam keluarga tersebut terutama dengan cara memberi contoh dan tiruan dan proses tersebut dilakukan dengan mengandalkan kekuatan memori. Hal tersebut akan terbentuk saat terjadi pensinergian antara guru menjadi orang tua yang mengajarkan nilai dan peradaban, konsep musik sebagai cara hidup, serta keberadaan murid magang untuk belajar musik yang direpresentasikan gurunya. Dalam hal ini, musik itu sendiri dibedakan dalam dua kategori yaitu lagu dan musik atau musik instrumental.

Dengan memasukkan lagu Pobin dalam musik budaya yang tumbuh melalui tradisi lisan, lagu Pobin pada dasarnya masuk dalam jajaran musik dunia dengan karakteristik perkembangan yang beragam atau heterogen. Keberagaman musik tradisi yang melekat pada kelompok masyarakatnya memiliki kekhasannya masing-masing. Setiap ras, etnis dan kelompok masyarakat tradisi memiliki lagu-lagu khusus yang berbeda satu dengan lainnya dan setiap grup menetapkan aturan musiknya ma- sing-masing. Oleh karena itu, musik tradisi selalu hidup dengan heterogenitas secara keseluruhan. Menurut Zoltán Kodály, aspek keragaman tersebut bukan hanya berakar pada bentuk musiknya yang berbeda melainkan juga tanggapan dan apresiasinya tumbuh dan berkembang secara berbeda dari anggota kelompoknya. Hal tersebut dipengaruhi oleh umur, kondisi sosial dan material, latar pendidikan dari masing-masing anggota, wilayah maupun gender (Titon, 1984). Oleh karena itu, musik tradisi dapat tumbuh dan lestari dalam masyarakatnya dan ada pula yang kemudian mati karena adanya pergerakan zaman yang membawa perubahan pada masyarakatnya atas musik tradisi tersebut.

Lagu Dalem merupakan lagu yang diciptakan setelah era lagu Pobin mulai menghilang. Lagu Dalem dinyanyikan dalam puisi atau pantun Melayu Tionghoa. Lagu-lagu Dalem ini karakternya dimainkan dengan irama yang kalem. Lagu ini diciptakan bukan untuk ngibing atau menari dalam tradisi Sunda. Lagu ini biasa dinyanyikan dalam suatu acara pada saat para tamu sedang menikmati hidangan yang tersedia. Dengan karakter lagu yang kalem, lagu jenis ini biasanya dipergunakan untuk mengukur kualitas vokal dari penyanyi gambang kromong.

Lagu Sayur merupakan lagu yang muncul dan tumbuh di era generasi berikutnya setelah era lagu Dalem. Lagu Sayur ini memiliki karakter yang berbeda dengan lagu Dalem. Lagu Sayur dipergunakan untuk menari atau ngibing sehingga mempergunakan irama yang lebih enerjik. Hingga saat ini masih banyak pemain gambang kromong yang dapat memainkan berbagai lagu Sayur.

Bentuk identitas baru juga diperlihatkan pada film Anak Naga Beranak Naga yang menjadikan kesenian gambang kromong sebagai penanda terjadinya percampuran budaya. Percampuran budaya tersebut bukan hanya dilihat dari percampuran pengaruh instrumen yang dipergunakan dalam pertunjukannya tetapi juga percampuran dalam konsep pertunjukannya. Percampuran konsep ini terlihat dengan masuknya unsur budaya lenong Betawi pada kesenian gambang kromong. Konsep lenong disisipkan dalam satu lagu yang ditunjukkan dalam film tersebut berjudul Stambul Jengki. 


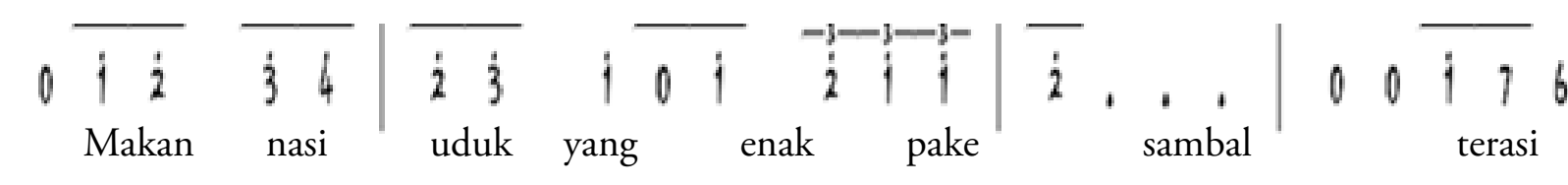

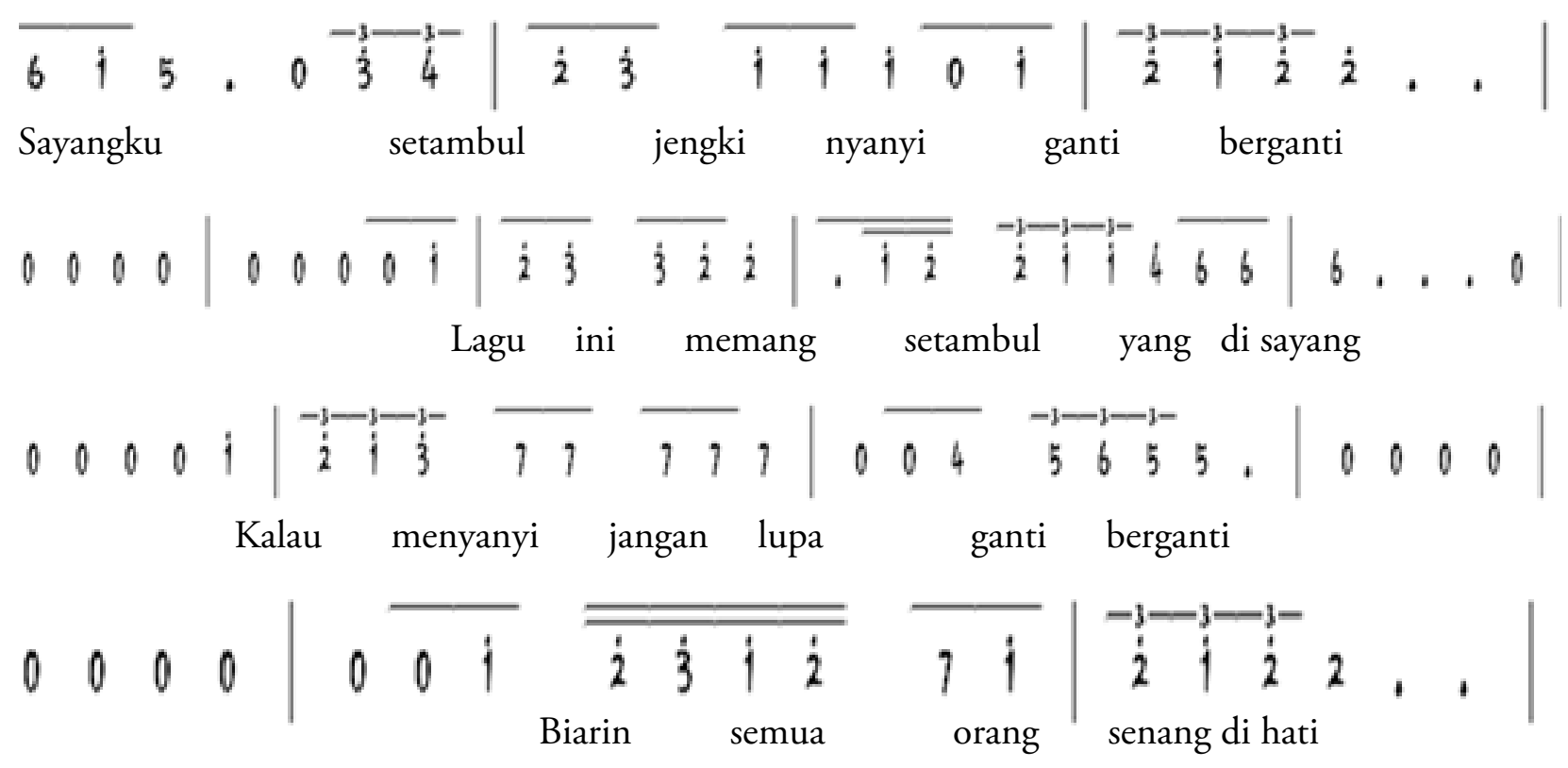

Lenong:

Penyanyi Laki-laki : 'Sopiah, ini lagu tahun 60an ciptaan Papah Teng Soei Ek'

Penyanyi Perempuan : 'Iya'

Penyanyi Laki-laki : 'Ciptaan dia tadinya memang tidak ada Stambul JEngki

Penyanyi Perempuan : 'Kagak ada, bang'

Penyanyi Laki-laki : 'Iya ciptaan dia...'

Penyanyi Perempuan : 'Kita cuma diturunin ini doang'

Ending: Lagu ini memang, Sopiah, Stambul Jengki. Jangan lupa hadirin, para undangan, malam ini harus kita hormati.

Lagu Stambul Jengki memiliki beberapa versi yang sangat berbeda satu dengan lainnya. Hal ini mengikuti percampuran lagu Pobin yang bersifat tradisi lisan dengan lagu Dalem yang mendapatkan pengaruh dari penggunaan pantun Melayu. Konsep lenong dalam Stambul Jengki menunjukkan adanya ketidaksamaan materi lagu antara lagu Stambul Jengki yang satu dengan Stambul Jengki lainnya seperti dalam dialog lenong tetapi liriknya tetap mempertimbangkan rima pada materi lirik seperti dalam pantun ciri budaya Melayu. Pantun tersebut merupakan bagian dari tradisi lisan yang tidak memiliki ketetapan dan kepastian atas isi materi yang disampaikan sehingga mengikuti improvisasi penyanyi.

\section{Strategi Difusi BUdaya pada Kesenian Gambang Kromong}

Identitas Tionghoa melalui difusi budaya pada kesenian gambang kromong merupakan identitas yang dikonstruksi oleh masyarakat Tionghoa pinggiran. Konstruksi ini bergerak untuk mengakar ke bawah pada masyarakat baik masyarakat dalam satu lingkup maupun masyarakat di luar lingkup etnisnya. Hal ini sekaligus menandai kehidupan ekonomi masyarakat Tionghoa pinggiran yang berada pada tataran menengah ke bawah sehingga lebih memilih untuk mempergunakan kesenian yang lentur sifatnya sebagai sarana berintegrasi dan berbaur dengan komponen masyarakat dari luar 
etnisnya. Berbeda dengan kehidupan masyarakat Tionghoa menengah ke atas, konstruksi identitas yang dibangun akan bergerak mengarah ke atas yaitu tertuju pada pola pendekatan masyarakat ekonomi kuat pada para pemegang kebijakan pemerintahan.

Identitas Tionghoa yang terbentuk melalui representasi keberadaan kesenian gambang kromong di Indonesia menunjukkan konsep identitas budaya hibrid yang cair dan mampu menembus sekat-sekat ciri budaya tunggal dari masing-masing lingkup etnisnya. Hal ini menjadi satu strategi kebertahanan masyarakat Tionghoa itu sendiri di Indonesia karena sesuai konsep Bhabha kemampuan untuk beradaptasi dapat dilakukan melalui strategi bermimikri yaitu menyerupai tetapi berbeda. $\mathrm{Hal}$ ini menjadikan Tionghoa-Indonesia muncul sebagai satu entitas yang berbeda yang tidak dapat disamakan dengan masyarakat Tionghoa di tanah Tiongkok. Demikian pula tidak menjadikan masyarakat Tionghoa menjadi sama dengan masyarakat dari berbagai etnis lainnya di Indonesia.

Strategi difusi yang dilakukan oleh masyarakat Tionghoa khususnya seniman gambang kromong melalui berbagai bentuk adaptasi memadukan beberapa bentuk budaya seperti keberadaan instrumen tehyan yang menjadi perpaduan bentuk dan cara memainkan dari instrumen erhu dengan rebab Jawa maupun rebab Dayak. Konsep perkembangan kesenian ini tidak hanya terpengaruh pada budaya-budaya setempat tetapi juga perkembangan kemajuan teknologi melalui penggunaan instrumen-instrumen technophone yang dimasukkan pada pertunjukan gambang kromong masa sekarang. Hal ini menunjukkan bahwa identitas cair ini tidak hanya dimunculkan terhadap kesediaan masyarakat Tionghoa menerima budaya dari luar kelompok etnisnya melainkan juga terbuka bagi masuknya pengaruh dari perubahan zaman. Proses adaptasi lainnya yang muncul pada kesenian gambang kromong juga ditunjukkan melalui lagu-lagu yang dibawakan dalam setiap pertunjukan gambang kromong. Meskipun pada dasarnya, setiap lagu yang dimainkan oleh kelompok gambang kromong dalam setiap pentasnya mengikuti permintaan dari pemesan atau penanggap pertunjukan tersebut, kelompok kesenian tersebut juga banyak memainkan lagu dengan memasukkan unsur lenong atau memainkan lagu keroncong dengan penggunaan instrumen gambang kromong. Dengan demikian, secara bentuk permainan, pertunjukan gambang kromong cenderung bersifat fleksibel.

Kesadaran bahwa melalui keindahan seni, orang dari berbagai elemen tanpa terbatasi etnis, usia, atau kategori pembeda lainnya mampu menyatu dalam menikmati keindahan seni, maka seniman gambang kromong maupun masyarakat Tionghoa pinggiran tetap melestarikan kesenian gambang kromong ini melalui pelibatan pertunjukan-pertunjukan gambang kromong sebagai sarana hiburan maupun bagian dari berbagai ritual acara Tionghoa seperti upacara kematian, acara pernikahan, dan perayaan ulang tahun kelenteng. Oleh karena itu, strategi berikutnya yang dilakukan agar kesenian gambang kromong terus bertahan sebagai sarana berintegrasi dengan berbagai budaya yang berkembang di Indonesia adalah melibatkannya sebagai kesenian hiburan rakyat dan salah satu bagian dari kehidupan ritual yang berjalan dalam kehidupan masyarakat Tionghoa. Hal ini menunjukkan adanya pola perluasan fungsi atas kesenian gambang kromong, mengingat pada zaman dahulu kesenian ini lebih berfungsi sebagai kesenian untuk menerima dan menjamu tamu orang Tionghoa yang datang ke Batavia. Dengan demikian, keberadaan kesenian gambang kromong zaman dahulu terkesan lebih eksklusif karena hanya dimainkan pada waktu-waktu tertentu saja sedangkan untuk masa sekarang kesenian ini banyak mengikuti hiburan rakyat juga di samping sebagai sarana acara-acara penting dalam kehidupan masyarakat Tionghoa. Perluasan fungsi tersebut membuktikan bahwa kesenian gambang kromong merupakan bentuk kesenian campur yang cair. Pola cairnya kesenian ini menunjukkan konstruksi identitas masyarakat Tionghoa khususnya pelaku-pelaku seni gambang kromong yang juga bersifat pragmatis dalam kehidupannya.

\section{Penutup}

Gambang Kromong sebagai salah satu bentuk budaya hibrid yang menampilkan kesenian 
campur muncul sebagai media akulturasi budaya yang mengiringi masuk dan berintegrasinya kehidupan masyarakat Tionghoa ke Indonesia. Berbagai aturan atau regulasi yang diterapkan pemerintah yang berkuasa sejak zaman kolonial membentuk konstruksi diskriminatif melalui pembagian kelompok masyarakat. Melalui sarana kesenian gambang kromong, proses berintegrasi ini dapat dilihat melalui satu strategi difusi budaya. Bentuk difusi budaya dapat dilihat dari adaptasi atas bentuk instrumen, tangga nada, lagu-lagu yang dipentaskan, maupun fungsi dari pertunjukan gambang kromong itu sendiri. Difusi ini mengiringi bentuk-bentuk percampuran dengan unsur budaya lainnya. Dengan demikian, kehidupan masyarakat ditinjau dari kehidupan berkesenian menunjukkan bahwa kehidupan masyarakat Tionghoa di tengah masyarakat Indonesia lainnya bersifat lentur dan cair.

Identitas Tionghoa yang terbentuk melalui perkembangan kesenian gambang kromong menunjukkan identitas yang heterogen. Kehidupan pelaku kesenian gambang kromong berada dalam taraf ekonomi menengah ke bawah. Hal tersebut memecah stereotip yang dilekatkan pada masyarakat Tionghoa bahwa masyarakat Tionghoa merupakan masyarakat ekonomi menengah ke atas. Selain itu, kehidupan masyarakat yang tertutup atau asosial tidak terepresentasi pada masyarakat pelaku gambang kromong. Kehidupan masyarakat Tionghoa membaur dengan masyarakat etnis lainnya melalui kesenian tersebut. Hal ini menunjukkan bahwa kehidupan kesenian gambang kromong mempengaruhi konstruksi kehidupan yang melekatkan identitas Tionghoa kepada masyarakat Tionghoa sebagai pelaku seninya. Namun demikian, identitas masyarakat Tionghoa tidak dapat ditentukan secara pasti bentuk konstruksinya karena kecairannya yang mampu menembus batas dan senantiasa menunjukkan perubahannya mengikuti berbagai perubahan zaman menjadikannya bentuk yang disidentifikasi.

\section{Kepustakaan}

Afif, A. (2012). Identitas Tionghoa Muslim Indonesia: Pergulatan Mencari Jati Diri. Depok: Kepik Bhabha, H. K. (1994). The Location of Culture. New York: Routledge.

Budiman, C. (2013). Retorik dan Makna Ideologis Karya Instalasi dalam Film Opera Jawa Garin Nugroho. RESITAL : JURNAL SENI PERTUNJUKAN, 14(1). doi: http://dx.doi. org/10.24821/resital.v14i1.390

Creswell, J. (2012). Research Design: Pendekatan Kualitatif, Kuantitatif, dan Mixed. Yogyakarta: Pustaka Pelajar.

Haryanto. (2015). Musik Suku Dayak: Sebuah Catatan Perjalanan di Pedalaman Kalimantan. Yogyakarta: BP ISI Yogyakarta.

Koentjaraningrat. 1990. Sejarah Teori Antropologi II. Jakarta: UI Press.

Kartika, B. (2015). Mengapa Selalu Harus Perempuan: Suatu Konstruksi Urban Pemenjaraan Seksual Hingga Hegemoni Maskulinitas dalam Film Soekarno. Journal of Urban Society's Arts, 2(1), 35-54. doi:http:// dx.doi.org/10.24821/jousa.v2i1.1268

Kustedja, S. (2012, Agustus 11). Jejak Komunitas Tionghoa dan Perkembangan Kota Bandung. Jurnal Sosioteknologi, 105-128

Kwa, D. (2012). Gambang Kromong and Wayang Cokek. Dalam M. N. Lily Wibisono (Penyunt.), Indonesian Chinese Peranakan: A Cultural Journey (hal. 320-323). Jakarta: Kompas Gramedia.

Said, E. (2010). Orientalisme: Menggugat Hegemoni Barat dan Mendudukkan Timur sebagai Subjek.

(A. Fawaid, Penerj.) Yogyakarta: Pustaka Pelajar.

Titon, M. S. (1984). The Music-Culture as a World Music. Dalam J. T. Jeff Todd Titon, World of Music: An Introduction to The Music of The World's People (hal. 1-11). New York: Schirmer Books.

Van Peursen, C.A. 2005. Strategi Kebudayaan. Terj. Dick Hartoko. Yogyakarta: Kanisius 